\title{
COMPARISON OF EMOTIONAL INTELLIGENCE OF STUDENTS ENROLLED IN SPECIAL EDUCATIONAL PROGRAM FOR INTELLECTUALLY GIFTED PUPILS AND PUPILS OF THE ORDINARY EDUCATIONAL ENVIRONMENT
}

\author{
[KOMPARACIA EMOCNEJ INTELIGENCIE ZIAKOV \\ SPECIALNEHO EDUKACNEHO PROGRAMU PRE INTELEKTOVO \\ NADANYCH ZIAKOV A ZIAKOV BEZNEHO EDUKACNEHO \\ PROSTREDIA]
}

\author{
Dusan Fabik
}

\section{doi: 10.18355/PG.2017.6.1.1}

\begin{abstract}
The aim of our research was to compare total score of emotional intelligence and its subscales among pupils enrolled in special educational program for intellectually gifted pupils and pupils of the ordinary educational environment.. 130 respondents of both sexes (age $\mathrm{M}=16,09 ; \mathrm{SD}=0,867$ ) participated on this research. We used The Trait Emotional Intelligence Questionnaire - short form to measure emotional intelligence. There were used descriptive statistics and Mann-Whitney test for the elaboration of the results. The results proved significant higher emotional intelligence among individuals enrolled in special forms of education in dimensions of well-being, emotionality, self-control and as well as in total score.
\end{abstract}

Key words

giftedness, emotional intelligence, adolescent

\begin{abstract}
Anotácia
Ciel'om výskumu bolo porovnat' celkové skóre emočnej inteligencie a jej subškály u žiakov špeciálneho edukačného programu pre intelektovo nadaných žiakov a žiakov bežného edukačného prostredia. Výskumu sa zúčastnilo 130 respondentov (vek $\mathrm{M}=16,09 ; \mathrm{SD}=0,867$ ) oboch pohlaví. Na meranie emočnej inteligencie bol použitý sebavýpovedný dotazník The Trait Emotional Intelligence Questionnaire - short form. Štatisticky boli výsledky spracované deskriptívnou štatistikou a Mann-Whitneyho testom. Výsledky preukázali signifikantne vyššiu emočnú inteligenciu u jednotlivcov špeciálnej formy vzdelávania $\mathrm{v}$ dimenziách well-being, emocionalita, sebakontrola, rovnako aj v celkovom skóre.
\end{abstract}

\section{Kl'účové slová}

nadanie, emočná inteligencia, adolescent

\section{Vymedzenie emočnej inteligencie}

V súčasnej odbornej literatúre neexistuje jednoznačná definícia pojmu emočná inteligencia (d’alej len EI). Miesto toho odborná literatúra ponúka tri základné koncepty emočnej inteligencie: „ability model“ (modely, ktoré chápu EI ako schopnost'); „trait model“ (modely EI, ktoré ju chápu ako črtu resp. vlastnost') a "mixed model“" (zmiešaný model).

Klasický "ability model" pochádza z roku 1990 od J. Mayera a P. Saloveya (1997). Neskôr, v roku 1997 P. Salovey a J. Mayer vydali revíziu svojho pôvodného modelu EI. V tomto prepracovanom modeli považovali EI za schopnost' rozpoznat' významy 
emocionálnych prejavov v sociálnych interakciách a na základe toho riešit' problémy. Model EI obsahuje štyri základné kategórie: vnímanie, posúdenie a vyjadrenie emócií; emocionálna facilitácia myslenia; pochopenie a analyzovanie emócie; regulácia emócií. Podl'a daného modelu, rovnako ako meranie všeobecnej inteligencie, tak aj meranie EI ako schopnosti, obsahuje správne a nesprávne odpovede. Merané zručnosti korelujú s inými kognitívnymi zručnost'ami a úroveň daných schopností narastá s vekom.

K. Petrides a A. Furnham $(2001,2006)$ zase navrhli model črtovej emočnej inteligencie. Tento model EI od K. Petridesa a jeho spolupracovníkov je prvým systematickým modelom EI ako črty "zahŕňajúci domény odvodené na základe obsahovej analýzy existujúcich modelov EI" (Salbot, 2011, s. 12). Tvorí ju 13 zložiek, ktoré sú začlenené do štyroch všeobecných faktorov, pričom sú dve zložky samostatné: 1. emocionalita (vyjadrenie emócií, empatia, emočné ocenenie, vzt'ahová kompetencia), 2. sociabilita (sociálne uvedomenie, asertivita, zvládanie emócií iných), 3. well-being (št'astie, optimizmus, sebaúcta), 4. sebakontrola (kontrola emócií, nízka impulzivita, zvládanie stresu), 5. samostatné zložky (adaptabilita, sebamotivácia) (Petrides et al., 2007). Najčastejšia nevýhoda modelov EI ako črta je ich závislost' na úprimnosti a dostatočnej miere sebapoznania respondentov. Ak sú tieto výpovede l’udí nepresné, dotazníky podávajú následne informácie iba $\mathrm{z}$ pohl'adu nepresných percepcií respondentov a nie o ich aktuálnych úrovniach EI (Wilhelm, 2005).

Zmiešané modely EI vychádzajú $\mathrm{z}$ teoretického základu modelu J. Mayera a $\mathrm{P}$. Saloveya, ale samotné spôsobilosti EI sú už merané sebaposudzovacími metódami, tak ako je to typické pre K. Petridesa v "trait modeli". Konceptu zmiešaného modelu sa venovali najmä D. Goleman a R. Bar-On. Podl'a modelu od Bar-Ona (2000) je EI prierez vzájomne prepojených emocionálnych a sociálnych kompetencií a spôsobilostí, ktoré určujú ako efektívne sme schopní pochopit' a vyjadrit' svoje emócie a emócie druhých. Zároveň je presvedčený, že EI sa v priebehu rokov vyvíja, a že je možné ju zlepšovat' prostredníctvom rôznych školení, programov, či terapie. Pôvodný model D. Golemana bol vytvorený v roku 1995 a pozmenený v roku 1998 tiež D. Golemanom. V revidovanej verzii navrhoval Goleman (in Bradberry \& Greaves, 2007) 4 zložky ako základné piliere EI s 20 emocionálnymi spôsobilost’ami: sebauvedomovanie a sebaovládanie (kombinácia motivácie a regulácie emócií), sociálne uvedomenie (kombinácia motivácie a empatie) a riadenie vzt'ahov (kombinácia motivácie, empatie a sociálnych spôsobilostí.) Hoci jeho publikácia spopularizovala koncept emočnej inteligencie, jej teoretický a empirický prínos je rozporuplný. D. Golemanova teória je považovaná za príliš globalizujúcu. Vychádza skôr z apriórnych predpokladov ako z vedeckých teórií.

\section{Emočná inteligencia nadaných žiakov}

Za nadaného žiaka považuje National Association for Gifted Children - NAGC (2008) tých jednotlivcov, ktorí "preukazujú vynikajúcu úroveň schopností (definovaná ako výnimočná schopnost' premýšl'at' a učit' sa), alebo spôsobilosti (výsledok najlepších $10 \%$ ) v jednej alebo viacerých domén". Obyčajne sa ako miera nadania poníma celková úroveň intelektových schopností nachádzajúcich sa v pásme horných $2 \%$ populačného ročníka (IQ 130).

V prípade nadaných žiakov a emočnej inteligencie je D. Goleman (1997) presvedčený, že akademická inteligencia má málo dočinenia s emočným životom. Tieto dve entity často korelujú, nie sú protikladmi, no skôr sa dopíňajú. Rovnaký názor má I. Wedlichová (2011), ktorá tiež vraví, že emočné spôsobilosti nie sú protikladom rozumových schopností, skôr sa dynamicky dopíñajú na pojmovej úrovni aj v skutočnom svete. Aj L. Shapiro (1998) je názoru, že v ideálnom prípade môže človek vynikat' v rozumových schopnostiach (byt' nadaný) a v súčasne aj v sociálnych a emočných spôsobilostiach. Odkazuje pritom na mená ako Thomas Jefferson alebo 
John F. Kennedy. Oproti tomu však množstvo odborníkov z oblasti nadania upozorňuje na emočné charakteristiky nadaných jedincov ako je zvýšená nevyzretost', citlivost' až precitlivelost', impulzivita, zvýšená emočná podpora, emočná expresia, odlišný zmysel pre humor. Niektoré charakteristiky sa môžu javit', že sa týkajú skôr temperamentu ako napr. impulzivita či emočná expresia, treba si však uvedomit', že aj tieto emočné charakteristiky sa objavujú v modeloch EI, konkrétne napr. model EI od K. Petridesa. A. Loh (2015) dokonca hovorí, že nadané deti a emočná inteligencia sú dva protichodné problémy a je teda $\mathrm{v}$ priamom rozpore $\mathrm{s}$ hore uvedenými autormi. Vyvstáva potom otázka či a aký vplyv má potom naozaj nadanie na emočnú ineligenciu?

Najvhodnejšie východisko poskytujú aktuálne štúdie. H. Sharifi a M. Sharifová (2014) porovnávali 60 nadaných a bežných študentov 2. ročníka strednej školy. Zistili, že emočná inteligencia je signifikantne vyššia u nadaných študentov. Ako metóda bola použitá 41 položková sebaposudzovacia škála Modified Schutte EI Scale (MSEIS) s 5-bodovou Likertovou škálou. Ďalšia štúdia z Iránu N. Etemadiho et al. (2015) porovnávala 100 nadaných a bežných chlapcov vo veku 14-17 rokov. Rovnako ako v predchádzajúcej štúdii bola použila metodiku MSEIS a prišla aj k rovnakým výsledkom. Nadaní študenti dosiahli signifikantne vyššie skóre v emočnej inteligencii. Posledná iránska štúdia (Karimi \& Besharat, 2010) porovnávala alexitýmiu a emočnú inteligenciu u 86 nadaných a 89 bežných stredoškolských študentov. Záver opät' preukázal lepšie pochopenie a organizovanie emočných situácii u nadaných ako pri bežných študentoch.

Štúdia od A. Singh a S. Kaur (2012) porovnávala až 200 bežných a 200 nadaných študentov vo veku 12 až 18 rokov. Zastúpené boli obe pohlavia. Rovnako ako vo vyššie uvedených štúdiách dosiahli nadaní študenti vyššiu emočnú inteligenciu ako bežní žiaci.

Ďalšia práca od S. Leeho a P. Olszewski-Kubiliusovej (2006) použila sebavýpovednú škálu Emotional Quotient Inventory (EQI). Výsledky preukázali, že nadaní jedinci nedosiahli celkové vyššie skóre $\mathrm{v}$ emocionálnej inteligencii (ani $\mathrm{v}$ jednotlivých častiach) v porovnaní so skupinou bežných žiakov. Nadané dievčatá však dosiahli celkové nižšie skóre emočnej inteligencie než bežné dievčatá. Podobné výsledky priniesla štúdia od M. Zeidnera et al. (2005), ktorá porovnávala 83 nadaných študentov a 125 bežných študentov z Izraela. Použité metódy boli Mayer-SaloveyCaruso Emotional Intelligence Test (MSCEIT) a sebavýpovedný Schutte Self-Report Inventory (SSRI). Zaujímavost’ou je, že nadaní študenti dosiahli vy̌šsie skóre v MSCEIT, ale naopak nižšie skóre v SSRI. Zistenia potvrdzujú tézu, že emočná inteligencia ako schopnost' má blízko ku kognitívnej inteligencii.

Posledná štúdia, ktorú prezentujeme je od J. Mayera et al. (in Bobáková, 2013), ktorí skúmali 11 nadaných adolescentov pomocou metódy Multifactor Emotional Intelligence Scale (MEIS). Výskumníci zistili vyššiu emočnú inteligenciu v škále identifikácia emócií a využitie emócií. Považujeme však nutné brat' do úvahy chudobnú výskumnú vzorku a absentujúcu kontrolnú skupinu.

Dovolíme si preto konštatovat', že aktuálne výskumné zistenia naznačujú rozvinuté emočné spôsobilosti nadaných žiakov, a to aj napriek niektorým tvrdeniam hovoriacich opak (napr. Loh, 2015).

\section{Výskumný problém}

Ciel'om predloženej štúdie je preskúmat' a popísat' charakteristiky emočnej inteligencie žiakov zo špeciálneho vzdelávacieho programu pre intelektovo nadaných žiakov. Zaujíma nás ako sa líšia ich emočné spôsobilosti od bežných žiakov. Ciel’om je porovnat' jednotlivé dimenzie emočnej inteligencie, rovnako aj celkové skóre. 


\section{Výskumná otázka}

Vzhl'adom na poznatky z prehl'adu relevantnej odbornej literatúry a v súlade s ciel'mi práce sme si stanovili túto výskumnú otázku:

VO: Existuje štatisticky významný rozdiel $\mathrm{v}$ emočnej inteligencii medzi žiakmi zo špeciálneho edukačného programu pre intelektovo nadaných žiakov a medzi žiakmi z bežného edukačného programu?

\section{Výskumná vzorka}

Výskumu sa zúčastnilo 130 respondentov. Žiakov zo špeciálneho vzdelávacieho programu pre intelektovo nadaných žiakov bolo 65; 40 chlapcov a 25 dievčat (študenti špeciálnej školy - Školy pre mimoriadne nadané deti a Gymnázium v Bratislave). Vo výskume ich pre jednoduchost' označujeme ako "nadaných". Podmienkou prijatia žiaka do vyššie uvedenej školy bolo IQ $\geq 130 \mathrm{v}$ teste WISC III.

Adolescentov z bežného vzdelávacieho programu bolo $65 ; 40$ chlapcov a 25 dievčat (študenti bežného gymnázia). V našom výskume ich označujeme ako "bežných". Pomocou deskriptívnej štatistiky sme zistili, že vekové rozloženie celej výskumnej bolo $(\mathrm{AM}=16,09 ; \mathrm{Md}=16 ; \mathrm{Mo}=17)$. Minimálny vek respondenta bol 14 rokov, maximálny 18 rokov.

\section{Metodika práce a metódy skúmania}

Vzhl'adom na stanovené ciele a vývinové obdobie výskumnej vzorky sme zvolili nasledujúcu výskumnú metódu: sebavýpovedný dotazník The Trait Emotional Intelligence Questionnaire - short form, d’alej len TEIQue, ktorý poníma emočnú inteligenciu ako črtu (Cooper \& Petrides, 2010). TEIQue dotazník obsahuje 30 položiek, kde pri každej respondenti vyberajú jednu odpoved' zo sedembodovej Likertovej škály (od 1 - úplne nesúhlasím po 7 - úplne súhlasím). Dotazník podáva informáciu o celkovom skóre EI a štyroch všeobecných faktoroch EI:

- well-being (Well-Being)- životná spokojnost';

- $\quad$ sebakontrola (Self-Control) - ovládanie a riadenie impulzov;

- $\quad$ sociabilita (Sociability) - prežívanie sociálnych kontextov;

- emocionalita (Emotionality) - porozumenie vlastným emóciám a emóciám druhých.

K. Petrides a A. Furnham (2006) uvádzajú Cronbachovu $\alpha$ vo svojej štúdii pre tento dotazník 0,84 u mužov a 0,89 u žien; v novších štúdiách od A. Coopera a K. Petridesa (2010) sa pohybuje $\mathrm{v}$ rozmedzí od 0,87 do 0,89 . V našom prípade je Cronbachova $\alpha \mathrm{v}$ rozmedzí $0,78-0,84$ pre celý výskumný súbor.

Dotazník bol administrovaný anonymne, a obsahoval len všeobecné identifikačné údaje, tzn. pohlavie a vek. Dáta boli aplikované a vyhodnocované pomocou programu IBM SPSS 20.0. Na výpočet normálneho rozloženia dát vo vzorke sme použili Kolmogorov-Smirnovov test normality. Normálne rozloženie sme nezistili v sledovaných položkách, preto na vyhodnocovanie používame neparametrický test. Použité štatistické metódy sú: deskriptívna štatistika a Mann-Whitney test.

\section{Analýza výsledkov výskumu a diskusia}

Existuje štatisticky významný rozdiel $\mathrm{v}$ emočnej inteligencii medzi žiakmi zo špeciálneho edukačného programu pre intelektovo nadaných žiakov a medzi žiakmi z bežného edukačného programu?

\begin{tabular}{|c|c|c|c|c|c|}
\hline Škála & Skupina & $\mathrm{N}$ & $\mathrm{AM}$ & $\mathrm{u}$-test & sig. \\
\hline Well-being & Nadaní & 65 & 31,369 & 1400,50 & $\mathbf{0 , 0 0 1}$ \\
\hline
\end{tabular}




\begin{tabular}{|c|c|c|c|c|c|}
\hline & Bežní & 65 & 29 & & \\
\hline \multirow{2}{*}{ Sebakontrola } & Nadaní & 65 & 26,646 & \multirow{2}{*}{2017,00} & \multirow{2}{*}{0,723} \\
\hline & Bežní & 65 & 26,292 & & \\
\hline \multirow{2}{*}{ Emocionalita } & Nadaní & 65 & 38,785 & \multirow{2}{*}{924,00} & \multirow{2}{*}{$\mathbf{0 , 0 0 0}$} \\
\hline & Bežní & 65 & 32,015 & & \\
\hline \multirow{2}{*}{ Sociabilita } & Nadaní & 65 & 29,754 & \multirow{2}{*}{1099,00} & \multirow{2}{*}{0,000} \\
\hline & Bežní & 65 & 25,646 & & \\
\hline \multirow{2}{*}{ Celková EI } & Nadaní & 65 & 145,015 & \multirow{2}{*}{1207,50} & \multirow{2}{*}{$\mathbf{0 , 0 0 0}$} \\
\hline & Bežní & 65 & 130,8 & & \\
\hline
\end{tabular}

\section{Tabul'ka 1: Výsledky Mann-Whitneyho testu $v$ jednotlivých škálach EI u nadaných a bežných adolescentov.}

Na základe uvedenej tabul'ky môžeme vidiet', že nadaní žiaci majú signifikantne vyššie skóre celkovej emočnej inteligencie $U=1207,50 ; p<0,01(p=0,000)$ ako bežní žiaci. Štatisticky významné rozdiely sa preukázali aj v niektorých d’alších škálach: well-being $U=1400,5 ; p<0,01(p=0,001)$; emocionalita $U=924,00 ; p<0,01(p=0,000)$ a sociabilita $U=1099,00 ; p<0,01 \quad(p=0,000)$. Vo všetkých vyššie uvedených subškálach EI dosiahli nadaní žiaci signifikantne vyššie skóre, čo znamená, že sa vyznačujú väčšou sociabilitou, emocionalitou a well-beingom.

Získané výsledky sú v súlade s najaktuálnejšími štúdiami (napr. Etemadiho et al., 2015; Sharifi \& Sharif, 2014; Singh \& Kaur, 2012; Karimi \& Besharat, 2010). Podobné výsledky už naznačovali aj staršie štúdie (napr. Alumran \& Punamäki, in Etemadi et al., 2015; Mayer et al., in Bobáková, 2013). Jediná štúdia, ktorá konštatuje nižšiu EI nadaných žiakov je od M. Zeidnera et al. (2005), kde je však nutné doplnit', že tá istá štúdia pri použití inej metóde zároveň hovorí o vyššej EI nadaných žiakov. Stotožňujeme sa preto s vyjadrením I. Wedlichovou (2011), ktorá vraví, že emočné spôsobilosti nie sú protikladom rozumových schopností a prijímame myšlienku od J. Alumrana a R. Punamäkiho (in Etemadi et al., 2015, p. 675), ktorí sú názoru, že "emočná inteligencia je priamo spojená s akademickým úspechom" 1 .

Vzhl'adom na niektoré štúdie zamerané na osobnost' nadaného adolescenta by sme mohli považovat' vyššiu miery sociability nadaného adolescenta za neštandardný výsledok. Viaceré výskumy a názory odborníkov sa totiž zhodujú v tom, že nadaní jedinci sú introvertne zameraní jedinci (napr. Sword, 2014; Sak, 2004; Silverman, 1992,1993) s horšími sociálnymi spôsobilost’ami (napr. Schechtnam \& Silektor, 2012; Tannenbaum, 1983). Na druhej strane však nájdeme aj výskumy, ktoré nekonštatujú signifikantne vyššiu introverziu alebo horšie sociálne zručnosti u nadaných žiakov (napr. Fábik, 2015; Limont et al., 2014; Laznibatová, 2012). Zostáva otázkou prečo jestvuje takýto rozpor v názoroch. Domnievame sa, že na vyššej úrovni sociability sa významne podiel'a špeciálny edukačný program pre nadaných žiakov. Už v útlom veku totiž nadané deti používajú komplikovanejšie a náročnejšie pravidlá hier, ktoré bežné deti $\mathrm{v}$ bežných podmienkach vzdelávania odmietajú. Toto odmietnutie sa následne interpretuje ako nezáujem o jeho osobu resp. diet’a sa domnieva, že ho iné deti "nemajú radi", čo obyčajne vedie k sociálnej izolácii. Vyskytujúca sa sociálna izolácia nadaných detí preukazovaná vo výskumoch (napr. Gross, 1993) teda nevyplýva $\mathrm{z}$ nadania samotného, ale je skôr dôsledkom absencie vhodnej skupiny rovesníkov (Neihart et al., 2002; Gross, 1993). Dovolíme si preto tvrdit', že v prostredí rovnakých nadaných žiakov sa neprejavujú výrazné odklony v introverzii/extravrezii alebo sociabilite, dokonca môžu dosiahnut' vyššie skóre. Na ich prirodzené živé, dynamické a vel'mi aktívne vystupovanie upozornilo už viacero autorov (napr. Colangelo \& Davis, 2003; Heller et al., 2000).

${ }^{1}$ v orig. "...emotional intelligence is directly associated with academic achievement." Slavonic Pedagogical Studies Journal, ISSN 1339-8660, Volume 6 Issue 1, February 2017 
Rovnako aj v problematike emocionality a well-beingu existujú rozporuplné názory. $\mathrm{Na}$ jednej strane sa často zdôrazňuje vlastnost' „overexacitabilities“ (výraznejšie a intenzívnejšie reakcie a vyjadrenia než majú bežní adolescenti), ktorá vedie k emočným problémom, no na druhej strane jestvuje množstvo dôkazov tvrdiacich opak. Napr. F. Rafati et al. (2014) vo svojej štúdii nepotvrdili, že by nadaní jedinci vykazovali významné rozdiely v rôznych psychických problémoch (napr. depresivita či anxieta) oproti bežným jedincom. Ani štúdie od J. Guignarda et al. (2012), I. PufalStruzikovej (1999) či M. Neihartovej (1999), ktoré rovnako porovnávali nadaných s bežnou adolescentnou skupinou nepotvrdili významne vyššie rozdiely v úzkosti resp. depresie u K. Sarouphimovej (2011). Za mimoriadne výpovednú považujeme metaanalýzu od L. Martinovej et al. (2010), ktorá nepreukázala významný rozdiel v depresivite nadaných a bežných mladistvých a dokonca preukázala významne nižšiu mieru úzkosti u nadaných jedincov. V štúdii od J. Hamma (2010) dosiahli nadaní žiaci v škále emočné sebaponímanie taktiež signifikantne vyššie skóre a štúdii d M. Alesiovej et al. (2015) signifikantne nižšiu mieru depresívnej nálady. Konštatujeme preto, že získané výsledky týkajúce sa emocionality a well-beingu môžu odrážat' reálny obraz prežívania nadaných jednotlivcov.

Pri vysvetlení a interpretácii týchto zistení (vyššej EI nadaných žiakov) sa môžeme opriet' aj o model a prístup emočného spracovania informácii od J. Grossa (in Etemadi et al., 2015). Na základe tohto modelu má interakcia psychických procesov a pridružených komponentov ako intelektové nadanie, kreativita či rýchlost' odpovede na prostredie zásadnú úlohu v schopnosti jednotlivcov vo vnímaní, poznávaní a riadení svojich emócií a druhých. Preto možno dospiet' k záveru, že nadaní l’udia sú vd'aka lepšiemu a rýchlejšiemu spracovaniu schopní jednoduchšie a prijímat' a analyzovat' emočné informácie a stimuly.

\section{Záver}

Práca preukázala signifikantne vyššiu emočnú inteligenciu žiakov špeciálneho vzdelávacieho programu pre intelektovo nadaných žiakov. Významný rozdiel sa preukázal v škálach emocionalita, well-being a sociabilita. Predpokladáme, že za vyššou emočnou inteligenciou týchto jedincov zrejme stojí interakcia psychických procesov, ktorá ul'ahčuje riadenie svojich emócií a taktiež špeciálna forma vzdelávania, ktorá poskytuje vhodné podmienky pre harmonický rozvoj osobnosti.

\section{Bibliographic references}

ALESI, M. - RAPPO, G. - PEPI, A. 2015. Emotional Profile and Intellectual Functioning: A Comparison Among Children With Bordeline Intellectual Functioning, Average Intellectual Funcioning, and Gifted Intellectual Functioning.

BAR-ON, R. 2000. Emotional and social intelligence: Insights from the Emotional Quotient Inventory. In Bar-On, R., Parker, J. D. (Eds.), The Handbook of Emotional Intelligence. San Francisco, CA: Jossey-Bass. ISBN 0787949841.

BOBAKOVA, M. 2013. Emocionalna inteligencia a zvladanie stresu u nadanych deti. Presov: Presovska univerzita. ISBN 978-80-555-0828-3.

BRADBERRY, T. - GREAVES, J. 2007. Emocni inteligence v praxi. 1. vyd. Praha: Columbus. ISBN 978-80-7249-220-6.

COLANGELO, N. - DAVIS, G. A. E. 2003. Handbook of Gifted Education. 3rd edition. Boston: Pearson Education, Inc. ISBN 0-205-34063-6.

COOPER, A. - PETRIDES, K. V. 2010. A psychometric analysis of the Trait Emotional Intelligence Questionnaire-Short Form (TEIQue-SF) using item response theory. In Journal of Personality Assessment. ISSN 0022-3891, vol. 92, no. 5, pp. 449.457.

ETERMADI, N. - ETERMADI, F. - KAMVAR, A. - KESHTKAR, M. SHAHAMATI, F. - SHAHAMATI, Z. 2015. Comparing Emotional Intelligence and 
Self-Efficacy in Gifted and Non-Gifted of male Students. In International Journal of Life Science and Medical Research. ISSN 2231-2935, vol. 5, no. 6, pp. 671-677.

FABIK, D. 2015. Charakteristika matematicky nadanych ziakov. In Slavonic Pedagogical Studies Journal. The Scientific Educational Journal. ISSN 1339-8660, vol. 4, no. 2, pp. 210-219.

GOLEMAN, D. 1997. Emocni inteligence. Praha: Columbus. ISBN 80-85928-48-5.

GROSS, M. U. M. 1993. Exceptionally Gifted Children. NY: Routledge. ISBN 9780415064163.

GUIGNARD, J. - JACQUET, A. - LUBART, T. 2012. Perfectionism and Anxiety: A Paradox in Intellectual Giftedness? In PloS one. ISSN 1932-6203, vol. 7, no. 7.

HAMM, J. 2010. Differences in academic, affect, competence, and social selfconcepts in homogeneously and heterogeneously grouped gifted students: dissertation. Western Carolina University, 2010. 59 pp.

HELLER, K. A. - MONKS, F. J. - SUBOTNIK, R. - STERNBERG, R. 2000. International Handbook of Giftedness and Talent. Oxford: Elsevier Science: Pergamon. ISBN 0-08-043796-6.

KARIMI, M. - BESHARAT, A. M. 2010. Comparison of alexithymia and emotional intelligence in gifted and non-gifted high school students. In Procedia - Social and Behavioral Sciences, vol. 5, pp. 753-756.

LAZNIBATOVA, J. 2012. Nadany ziak na zakladnej, strednej a vysokej škole. Bratislava: IRIS. ISBN 978-80-89256-87-7.

LEE, S. - OLSZEWSKI-KUBILIUS, P. 2006. The Emotional intelligence, Moral Judgement, and Leadership of Academically Gifted Adolescents. In Journal for the Education of the Gifted. ISSN 0162-3532, vol. 30, no. 1, pp. 29-69.

LIMONT, W. - DRESZER-DROGOROB, J. - BEDYNSKA, S. - SLIWINSKA, K. JASTRZEBSKA. 2014. 'Old wine in new bottles'? Relationships between overexcitabilities, the Big Five personality traits and giftedness in adolescents. In Personality and Individual Differences. ISSN 0191-8869, vol. 69, pp. 199-204.

LOH, A. 2015. Emotional Intelligence and Gifted Children.[online]. [cit. 2015-0917]. Dostupné na: http:/www.brainy-child.com/article/emotional-intelligencequotient.shtml.

MARTIN, L. - BURNS, R. - SCHONLAU, M. 2010. Mental Disorders Among Gifted and Nongifted Youth: A Selected Review of the Epidemiologic Literature. In Gifted Child Quarterly. ISSN, vol. 54, no. 1, pp. 31-41.

MAYER, J. D. - SALOVEY, P. 1997. What is emotional intelligence? In Salovey, P., Sluyter, D. (Eds.), Emotional development and emotional intelligence: Implications for educators. New York: Basic Books. p. 3-31. ISBN 0465095879.

NATIONAL ASSOCIATION FOR GIFTED CHILDREN. 2008. What is Giftedness? [online]. [cit. 2015-11-09]. Dostupne na internete: http://www.nagc.org/ whatisgiftedness.aspx.

NEIHART, M. 1999. The impact of giftedness on psychological well-being. In Roeper Review. ISSN 0278-3193, vol. 22, no. 1, pp. 4-22.

NEIHART, S. - REIS, M. S. - ROBINSON, M. N. - MOON, S. (Eds.). 2002. The Social and Emotional Development of Gifted Children: What Do We Know?. Washington: Prufrock Press, 2002.

PAHL, N. 2008. The Role of Emotional Intellingence in Leadership. Norderstedt Germany: GRIN Verlag. ISBN 978-3-640-30334-2.

PETRIDES, K. - PITA, R. - KOKKINAKI, F. 2007. The location of trait emotional intelligence in personality factor space. In British Journal of Psychology. ISSN 20448295, vol. 98, pp. 273-289.

PETRIDES, V. K. - FURNHAM, A. 2001. Trait Emotional Intelligence: Psychometric Investigation with Reference to Established Trait Taxonomies. In European Journal of Personality, ISSN 0890-2070, vol. 15, no. 6, pp. 425-448.

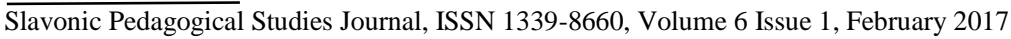


PETRIDES, K. V. - FURNHAM, A. 2006. The role of trait emotional intelligence I a gender-specific model of organizational variables. In Journal of Applied Social Psychology. ISSN 0021-9029, vol. 36, no. 2, pp. 552-569.

PUFAL - STRUZIK, I. 1999. Self- actualization and other personality dimensions as predictors of mental health of intellectually gifted students. In Roeper Review. ISSN 0278-3193, vol. 22, no. 1, pp. $44-47$.

RAFATI, F. - RAFATI, S. - MASHAYEKHI, F. - PILEHVARZADEH, M. MASHAYEKH. 2014. The comparison of the mental health and self-esteem in the gifted and normal adolescents of high schools in Jiroft City in the year 2012-2013. In International Journal of Current Research and Academic Review. ISSN 2347-3215, vol. 2 , no. 6, pp. 220-228.

SAK, U. 2004. A synthesis of research on psychological types of gifted adolescents. In Journal of Secondary Gifted Education. ISSN 1077-4610, vol. 15, no. 2, pp. 70-79. SALBOT a kol. 2011. Crtova emocionalna inteligencia a psychometricke vlastnosti nastrojov na jej meranie. [online]. Banska Bystrica, 2011. s. 12. [cit. 2013-05-06] Dostupné na internete: http://www.psychometriclab.com/admins/files/Salbot\%20a\%20kol.pdf.

SAROUPHIM, K. 2011. Gifted and Non-Gifted Lebanese Adolescents: Gender Differences in Self-Concept, Self-Esteem and Depression. In International Education. ISSN 0160-5429, vol. 41, no. 1, pp. 26-41.

SCHECHTMAN, Z. - SILEKTOR, A. 2012. Social competencies and difficulties of gifted children compared to nongifted peers. In Roeper Review. ISSN 0278-3193, vol. 34, pp. 63-72.

SHAPIRO, E. L. 1998. How to Raise a Child with a High EQ: A Parents Guide to Emotional Intelligence. New York: HarperPerennial. ISBN 0-06-092891-3.

SHARIFI, H. - SHARIFI, M. 2014. Comparing Emotional Intelligence and Humor in Gifted and Non-gifted Students. In Indian Journal of Scientific Research. ISSN 09762876, vol. 7, no. 1, pp. 1319-1324.

SILVERMAN, L. K. 1993. Counseling the gifted and talented. Denver: Love. ISBN 978-0891082736.

SILVERMAN, L. K. 1992. Counseling the gifted individual. In Counseling and Human Development, vol. 25, no. 4, pp. 1-14.

SINGH, A. - KAUR, S. 2012. A Comparative Study of Gifted and Non-gifted Children on Emotional Intelligence. In Indian Journal of Positive Psychology. ISSN 2229-4937, vol. 3, no. 1, pp. 14-19.

SWORD, L. 2014. The Gifted Introvert. [online]. [cit. 2014-09-09]. Dostupné na internete: http://highability.org/the-gifted-introvert/

TANNENBAUM, J. A. 1983. Gifted Children: Psychological and Educational Perspectives. Punta Gorda: Macmillan Pub Co. ISBN 978-0024188809.

WEDLICHOVA, I. 2011. Emocni inteligence. Ustí nad Labem: Univerzita J. E. Purkyne. ISBN 978-80-7414-347-2.

WILHELM, O. 2005. Measures of Emotional Intelligence: Practice and Standards. In Schulze, R., Roberts, R. (Eds.), Emotional Intelligence: An international handbook. Ashland, OH: Hogrefe \& Huber Publishers. p. 131- 154. ISBN 978-0889372832

ZEIDNER, M. - SHANI-ZINOVICH, I. - MATTHEWS, G. - ROBERTS, R. 2005. Assessing emotional intelligence in gifted and non-gifted high school students: Outcomes depend on the measure. In Intelligence. ISSN 0160-2896, vol. 33, no. 4, pp. 369-391. 
PhDr. PaedDr. Dušan Fábik

Faculty of Education, Comenius University in Bratislava

Department of Psychology and Pathopsychology

Moskovská ul. 3, 81108 Bratislava

Slovakia

fabik7@uniba.sk 